\title{
Oppositional Politics and the Internet in Iran: A Visual Semiotic Analysis of the Iranian Green Path Movement's Website
}

\author{
Yousef Mostafalou
}

Post-graduate student, Department of Media Studies, Faculty of Arts and Social Sciences University of Malaya, 50603 Kuala Lumpur, Malaysia; Email: mostafalou500@yahoo.com

Hamedi M. Adnan

Associate Professor and Head, Department of Media Studies, Faculty of Arts and Social Sciences University of Malaya, 50603 Kuala Lumpur, Malaysia; Email: hamedi@um.edu.my

\section{Doi:10.5901/mjss.2016.v7n2s1p113}

\section{Abstract}

This article analyzes the Iranian Green Movement's websites for promotion of their cultural and political struggle against the Islamic Republic of Iran's oppressive policies. It analyzes the website contribution in four different conditions that establish the movement: the alternative forms of information, culture and meaning production and dissemination for representation and reconstruction of collective identity, the networking and developing of alliance and solidarity between oppositional movement's activists, the organization and mobilization of public demonstration, and the direct expression of political protests. The goals of the study are to illustrate ways in which the Internet is utilized by the Iranian oppositional movement activists to promote and advance their cultural and political struggles. Toward this end, Roland Barthes's visual semiotic approach has been deployed to analyze the Iranian oppositional movement's websites and texts. Findings of the study show that the Internet or websites have being extensively used by the Iranian Green Movement's activists for the promotion of the alternative forms of information, culture and meanings for representation and reconstruction of collective identity, the organization and mobilization of public demonstration, the networking and development of alliance and solidarity between oppositional movement's activists and the direct expression of political protests. But, the Iranian Green Movement activists do not used full potential of the internet and website for promotion of their political struggles

Keywords: The Internet; Oppositional politics; Oppositional political movement; Collective identity; Alliance and solidarity; Visual semiotic analysis.

\section{Introduction}

New information and communication technologies (NICTs), especially the Internet, can be used by oppositional movements for promotion of their cultural and political struggles against totalitarian states (Atton, 2001; Downey \& Fenton, 2003; Downing, 2008; Kellner, 1999; Pickerill, 2006; Warf \& Grimes, 1997). The Internet has been used for oppositional politics since its inception in Iran (Aday et al., 2010; Kamalipour, 2010; Rahimi, 2011; Sreberny \& Khiabany, 2010; Wojcieszak \& Smith, 2014). In the context of the article, the oppositional politics refers to the public collective challenge against the totalitarian state's hegemonic and oppressive policies and cultural codes (Ayres, 1999; McAdam, Tarrow, \& Tilly, 2003; Tilly \& Tarrow, 2006). The Internet has been defined by DiMaggio et al. (2001) as the electronic network that links people and information through computers and other digital devices allowing person-to-person communication and information retrieval.

Parallel to Kahn and Kellner's $(2003,2005,2007)$ perspective, the main argument of this article is that the Internet as a "contested terrain" or an "alternative media" can be used by the Iranian oppositional movement for the promotion of their political interests and agendas. By oppositional deployment of the Internet technologies, the Iranian Green Movement's activists mediated their political struggles against the oppressive policies of the Islamic Republic of Iran's theocratic state. It contributes to a progressive cultural and political struggle, and helps to reproduce alternative forms of cultures, information and meaning for representation and reconstruction of their collective identities.

The proponents of new information and communication technologies claimed that the Internet substantially strengthened oppositional movements in Iran and "Arab Springs" (Grossman, 2009; Howard et al., 2011; Michaelsen, 2011). From an entirely different perspective, the opponents of the new communication technologies claimed that the 
Internet reinforced, strengthened, and reestablished the forces of the Islamic Republic of Iran's totalitarian state domination (Morozov, 2011). The problem that arises, if it does, is how the Internet is an instrument of empowerment, self-valorization, democratization and emancipation or an instrument of domination, suppression and exploitation. The present study attempts to address this issue through visual semiotic analysis of the Iranian Green Movement's websites to articulate and illuminate the oppositional deployment of the Internet for promotion of their political struggle against the Islamic Republic of Iran's oppressive policies.

The question that arises, if it does, is how the Internet makes possible the creation of a relatively safe environment where a variety of excluded and sub-cultural groups are able to resist hegemonic culture, identity and ideologies. Besides, how would they reproduce and circulate their own progressive and alternative forms of culture, meaning and ideologies and represent their oppositional identities which may challenge the status quo of culture and politics and produce a new political vision?

The Internet as a "contested terrain" or "alternative multimedia" has several functions for oppositional movements to advance their struggles against oppressive policies of dominant systems and totalitarian states. Van Aelst and Walgrave (2002) examines the contribution of websites to three different conditions that establish movement formation: collective identity, actual mobilization, and a network of organizations. Van Aelst and Walgrave (2002) examined the positive contribution of website to establish of oppositional movements and they ignored the negative effects of the website on disestablish of oppositional movements. Furthermore, Van De Donk et al. (2004) observe that the Internet offers revolutionary prospects for social movements to reach out to a global audience, circumventing the official political organizations and mainstream media message, to provide powerful tools for coordinating activities between the geographical diaspora and for constructing collective identity. Van De Donk et al. (2004) less pay attention to the role of Internet in fragmentation and "cyberbalkanization" communities and groups to "like-minded" groups which may weakened the social movements.

Moreover, Kahn and Kellner (2004) highlighted the Internet functions for oppositional political movements as an alternative forms of culture and information production and dissemination; as a collective identity representation and reconstruction; organization and mobilization public demonstrations and developing networks of solidarity and alliance among political movements activists and direct expression of political struggles. Additionally, Della Porta and Mosca (2005) offer a typology that highlights the Internet contribution in social movement and collective action as follow: firstly, "its purely instrumental use is helpful in the organization and the logistics of demonstrations, and as a means for different groups to keep networked. Secondly, the Internet can also be a specific means for the direct expression of dissent and protest. Thirdly, it has a cognitive function, enabling information to be disseminated and public opinion to be sensitized to issues scantily covered by mainstream media, and also reinforce collective identities" (p. 167).

Baringhorst (2008) summed up different functions of mediated communication of media for political protest in the five following parts: the logistic functions of protest mobilization; the cognitive function of knowledge production and communication in Net-based publics; the affective function of virtual community formation; the tactical function of using the Internet as a weapon and target of political protest; and the function of social organization in terms of transnational network formation. Additionally, Stein (2009) highlighted web use by the social movements in six parts: provides information, assists action and mobilization, promotes interaction and dialog, makes lateral linkages, serves as an outlet for creative expression, and promotes fundraising and resource generation. Furthermore, Laer et al. (2010) represented a twofold typology of a new digitalized collective action repertoire for social movements. Based on their model, the Internet can facilitate and support traditional offline collective action in terms of organization, mobilization, and transnationalization such as street demonstrations, rallies, and strikes. Moreover, the Internet creates virtual modes of collective action in terms of alternative website and weblog creation, signing online petitions, cultural jamming, hacking, and email bombings

Drawing from the above literature, it could be summarized that the Internet positive functions for oppositional movements as a site of dissemination and generation of alternative forms of information, culture, and meaning for the representation and reconstruction of collative identity; as the site of organization and mobilization of mass demonstration; as the site of development/representation of their solidarity and alliance; and as the site for direct expression of political protest and virtual struggles.

\section{Literature Review}

The Internet as a "contested terrain" or as an "alternative media" facilitates the production and dissemination of alternative forms of information, culture and meaning for representation and reconstruction of oppositional movements identities for insiders and outsiders of the movement (Atton, 2001; Bennett \& Segerberg, 2011; Della Porta \& Mosca, 2005; Kellner, 2001; Stein, 2009). While the state media often systematically misrepresents, negatively casts, and 
ignores oppositional movement's identity and ideology (Stein, 2009), the Internet provides oppositional movements with alternative media to counter the mainstream media misrepresented and distorted identity and ideology through the production and dissemination of alternative forms of culture, information, and meaning. According to Kahn and Kellner (2003), the oppositional deployment of the Internet facilitates the production of oppositional cultures against hegemonic and governing cultures of the established societies through changing and transforming the dominant system and ruling force's hegemonic cultural codes, meanings and myths which make possible the representation and reconstruction of their collective identity. In line with their argument, this article argues that the Iranian Green Movement produces its own cultural and political signs, symbols and meanings against the Islamic Republic of Iran's theocratic state's hegemonic culture and politics and represents their collective identity for a global audience.

The Internet may facilitate participation, organization and mobilization of the social movement's activists (Baringhorst, 2008; Van Aelst \& Walgrave, 2002; Vegh, 2003). Baringhorst (2008) argues that transaction costs of protest mobilization events have been reduced by the Internet technologies because of its high speed and spatial range of communication. Della Porta \& Mosca (2005) argue that the Internet because of "horizontal", "bi-directional" and "interactive features" facilitate internal and external communication between organization, groups and individuals in international level so that it enabled the organization and groups to send same massages to thousandths addresses and overcome the time and place limitation that facilitate international political protest mobilization. Similarly, Vegh (2003) argues that the Internet facilitates organization and mobilization by three means: (1) calling for offline action via e-mail or a website; (2) calling for online action for something typically done offline, such as sending e-mails to Congress members instead of letters; and (3) calling for online action that is possible only via the Internet, such as computer spam campaigns. Their arguments help us to argue that the Internet as contested terrain or as an alternative media can be used by oppositional and social movement activists to organize and mobilize public demonstrations.

In contrast to the postmodern "identity politics" perspective that promotes apolitical individualism, social atomized, fragmented, disintegrated, disconnected and cyber-balkanized individual, community, and society, Kahn and Kellner (2004) attempt to promote the politics of alliance and solidarity between different diverse groups and sub-cultures. From their perspective, the Internet network system facilitates linkage between diverse groups and communities that provide a basis for development of politics of alliance and solidarity to overcome the limitation of postmodern identity politics (Best \& Kellner, 1998).

The Internet can be used by oppositional movements as a weapon and target of direct expression of their political struggles (Della Porta \& Mosca, 2005; Van Laer \& Van Aelst, 2010). The term "electronic civic disobedience" refers to the oppositional deployment of digital technologies and cyberspace to influence the process of making decisions or to support efforts for policy changes (Hick \& McNutt, 2002: 8). Based on Van Laer \& Van Aelst's (2010) model, most widelyknown and used forms of online protest action consist of creation of alternative and protest websites and weblogs, hachtivism, culture jamming, email bombing/virtual sit ins, signing online petitions, organizing oppositional campaigns and so on. Based on their model, this article argues that the World Wide Web can be used by Iranian oppositional movements' activists as a weapon to directly express their political struggles against the dominant system's oppressive and distractive policies. To sum up, the article argue that oppositional political movements take advantage of ICTs for production and dissemination of alternative forms of information and culture and meaning for representation and reconstruction of collective identity, organizing the mobilization of mass demonstration, Networking and developing of alliance and solidarity and direct expression of political struggle

\section{Methodology}

The Visual Semiotic Approach of Roland Barthes $(1968,1972,1977)$ is deployed for analysis of the Iranian oppositional movement's websites and visual texts. From the perspective of Barthes (Barthes, 1968, 1977), "semiotics" or "semiology" has defined the system of sign or system of signification that forms the content of culture and ideology of societies. Therefore, his visual semiotic analysis is suitable for the representation of cultures and ideologies of societies.

The semiotic model of Barthes outlines three levels of signification, which consist of denotation, connotation, and myth or mythology (Barthes, 1972; Chandler, 2000; Kress \& Van Leeuwen, 2006). From the Barthesian visual semiotics perspective, the denotative level refers to what we actually see in the images and photographs. The connotative level refers to the meaning of what we see in images and photographs. From Barthes's perspective, the myth refers to cultural values and beliefs that are expressed at the level of connotation. Myth refers to a hidden set of rules and conventions through which meanings seem to be universal and natural. From his perspective, myths are the dominant ideologies of our time. Barthes (1972) argues that the organization of signs encodes particular messages and ideologies and that these ideologies can be revealed as constructed through textual analysis. He describes these constructed messages and 
ideologies as myths.

The website of Green Path Movement has been selected as a case study of the Iranian Green Movement's websites. The study's data collected from the first screenshot of the Iranian Green Path Movement's website and a screenshot of their visual texts for exploring meanings and codes of their visual signs. The collected data have been saved and recorded for analysis of their denotative, connotative, and mythical meanings based on Barthes's visual semiotic analysis.

\section{Findings}

The Green Path Movement website covers the Iranian Green Movement's events and leader's views. The Green Path Movement is analytical news network that organized by the Iranian religious reformist political writers and analysts. According to the Green Path Movement website, "the Green Path Movement is a strategic, analytic and news network that publish because of promotion, strength of the Iranian Green Movement by the Iranian reformist political writers and analysts" (the Green Path Movement, 2010, retrived from http://www.rahesabz.net; 26 June 2013). It is proposed that "the network, until future notice, run overseas duo to the Iran's current situation. But its approach is entirely adopted with the Iranian Green Movement aspirations and goals for the sake of the Iranian nation sovereignty in their own destiny. The media network produce and publish content with regard to countries current possibilities, opportunities and constraints" (the Green Path Movement, 2010, retrived from http://www.rahesabz.net; 26 June 2013).

According to the website, the Green Path Movement is Iranian network, independent, egalitarian, ethical, freedom, human rights defender, democratic, Islamic, anti-violence and follower of realism and moderation. The goals represent the green path movement's identity. Interestingly, while majority of them were clergies, Muslims, and religious writers, they are striving for secularism, democracy, and human rights and struggle against the absolute rule of the Jurist; Vellayat-e-Motlaghe Faghieh; and consider it as clear example of religious despotism at the current time. In following section, their website home page will be analyzed.

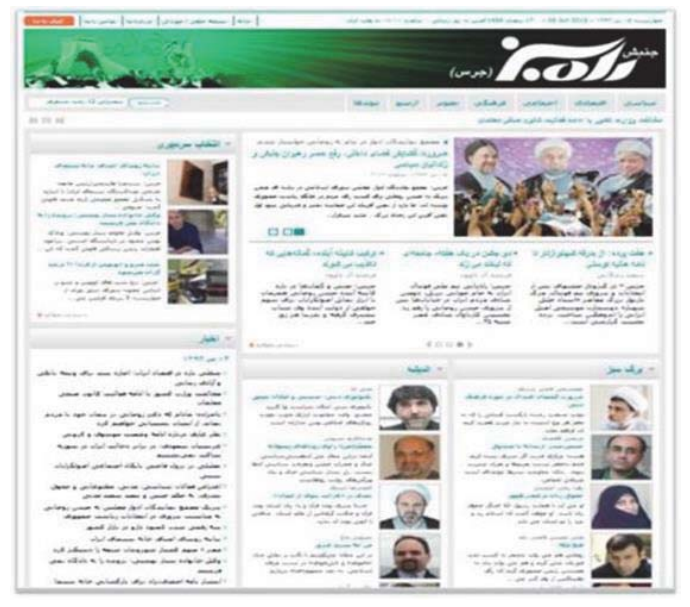

Figure 1: The first screen shot of the Green Path Movement website; http://www.rahesabz.net; 26 June 2013; @ Green Path Movement 2010

This is the first screen shot of the Green Path Movement website, http://www.rahesabz.net, and its title name is the Green Path Movement; جنش راه سبز with its abbreviation in Persian language; جرس. The most useful starting point of understanding the groups identity is understanding of the meaning of the group's name. At the denotative level it stands for the Iranian Green Movement, the Iranian Green Movement refers to a political movement that arose after the 2009 Iranian presidential election, in which protesters demanded removal of Mahmoud Ahmadinejad from office. At the connotative level it connotes the Green Path Movement is a strategic, analytic and news network that is publishing because of the propagation, strengthens and promotion of the Iranian Green Movement aims by the Iranian reformist's political writers and analysts. According to the Green Path Movement, the Green Path Movement is a strategic, analytic 
and news network that is publishing because of the propagation, strengthens and promotion of the Iranian Green Movement aims by the Iranian reformist's political writers and analysts. It is proposed that "the network, until future notice, run overseas duo to the Iran's current bottlenecks. But its approach is entirely adopted with the Iranian Green Movement aspirations and goals for the sake of the Iranian nation sovereignty rights in their own destiny. The media network produce and publish content with regard to countries current possibilities, opportunities and constraints.

At the top of the header of the website is embedded a calendar of the website-the Persian, Islamic and Gregorian calendars that show the website is updated, dynamic and active. At the top left side of the header of the website is set link to home, Mobil/manuscript that provide access to the latest news. The header of the website is covered with dark green colour, title name, sunshine, Azadi Square Tower, demonstration, Allah-O-Akbar, green colour in Iranian culture is sign of fertility, regeneracy, life, hope, happiness, spring and youth. In Islamic culture, it stands for firmly believe in Islam, God and resurrection. Title name represents these networks identity as supporter of reform and Iranian Green Movement, demonstration with raised hand with $\vee$ shape that symbolized protest against the result of the presidential election and victory of Iranian Green Movement, sunlight is sign of brightness and word of Allah-O-Akbar-an Islamic phrase that called Takbir in Arabic, meaning "God is the greatest" stands for believe in God and Islamic ideology. Under the header of the website is a strip that composed link navigation include political, economic, social, cultural, visual topics, archive and links. Under the strip is set a space for headline of latest news that in this case related to disagreement of the minster of the interior with continuation of activities of the Iranian Teacher Association which stands for unlawful of teacher union and syndicate under the Islamic Republic of Iran's theocratic state and associate it to Islamic system anti-syndicalism and unionism and repression of syndicates and unions under the Islamic system.

The main body of the website is covered with the website rotating headline box that include latest head line related to association of formers parliament representatives in a massage to Hassan Rouhani demand for necessity of opening of the domestic political space, siege of the Green Movement leaders and release of political prisoners that stands for oppression of critical political activism that at the connotative level stands for oppressive domestic policies of the Islamic Republic of Iran's. At the left side of the rotating headline box is set a rectangle that titled the editorial selection that include texts; the statement of head of guilds of Iranian cinema house and Sattar Beheshti's, an Iranian blogger who died under torture in custody. At the mythical level it demyth the Islamic Republic of Iran's brutality and violence.

Other space of main body of the website divided to three parts or three columns. The right side is allocated to green leaf that covered with articles from Iranian reformists such as Mohammad Taghi Fazel Maibody article on necessity of moderate discourse in religious cultural sphere, Morteza Kazemian article on the Green Movement from shadow to box and so on. Middle column is allocated to thought that include Hassan Paya's article about religious technology, Abdolkarim Soroush's article about Mohammad (PBUH) narrator of prophecy dreams and so on.

Next right column that titled Ghalam, pen, deal with the some articles such as Mohammad Reza Ghasemei's article on meaning and concept of democracy in our easy language, and Taymaz Azimi's article about moderation. The next rectangle deal with to the guests articles_-Abbas Abdi's article on dual line of compromise and resistance, Mostafa Ezadi article on rightists view on Hassan Rohani, news of Iran and world and last rectangle titled citizens wrote that include, Amire Razaghis letter to Hassan Rohani and Ehsan Samsam's letter to people selected chief and so on.

Middle column include the website interview with some political activists, prisoners family and figures such as interview with Amir Hossein Fadaee family and Mehdi Tajic interview with Ali Mazroee. Next part allocated to visual and vocal section that include letter of Ayatollah Tahery to his family from exile, and motto of Mir Hossein release. Next part is allocated to more information that include Amir Mohebian article on Hardliners and Hassan Rouhanis government and Hamid Rasaes article, Guardian Council thinks in this analysis and so on. The last part of this section deal with some historical documents like Ayatollah Azari Ghomeis letter to Resalat foundation and Ayatollah Taheries article about the 2009 election.

The use of visible colours like black, white and red colours reflect the popular appeal. The red colour gives the logo a bright and attractive look whereas black and white appeals the broad spectrum of viewers. FriendFeed is a real-time feed aggregator that consolidates the updates from social media and social networking websites, social bookmarking websites, blogs and micro-blogging updates, as well as any other type of RSS/ Atom feed. Tweeter logo has a white colour on a light blue background that symbolize an online social networking service that enables users to send and read short 140-character messages called "tweets". The blue colour in the Twitter logo signifies communication, and reliability, whereas the white colour stands for purity and emotion Facebook. this logo has a white on a light and dark blue background. The footer of the website is covered with link navigation and copyright sentence. The following examples show how the Internet be used by the Iranian Green Movement activists to disseminate alternative forms of culture, information and meaning for representation and reconstruction of their collective identity for themselves and their members. 


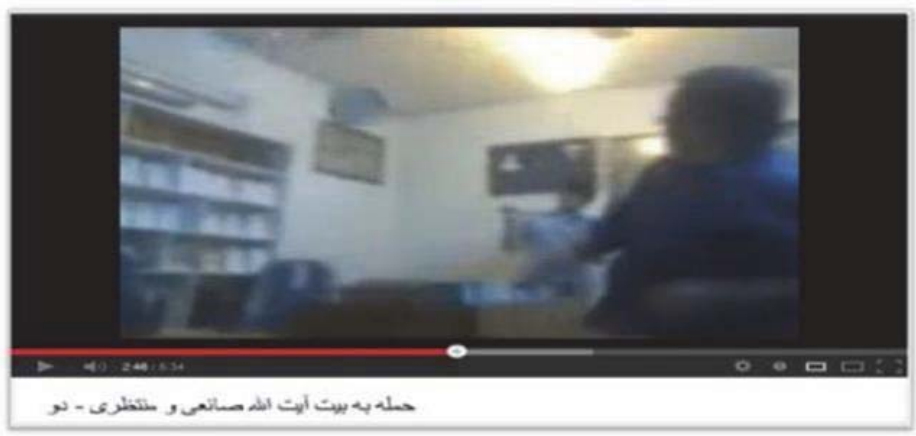

Figure 2: Still image adopted from a video tubes on plain clothes and the Basij members attack to grand Ayatollah Montazeri and Sanei houses and offices; http://www.rahesabz.net/story/18295, 10 October 2014; (c) Green Path Movement 2010

At the denotative level this is a video clip on the Basij member's midnight attack to grand Ayatollah Montazeri and Sanei houses and offices. In this clip, the plain clothes and the Basij members attack to Ayatollah Montazeri and Sanei houses and offices at midnight and completely destroyed it. The attackers broke the door and windows and destroyed everything. In response, somebody says that they were operation forces. After they completely ruined the house and office, they call their members out because they understand that there is camera inside the houses. In this moment, the camera zoom in on the motto written on the door or wall that says BBC English. Then after cameraman enter to the houses, one of them asks to take the Qurans and other religious books. Cameraman shows all rooms that Basij member are destroying them. One of them asks to take care of themselves. Inside a room Basij members brutally destroy the book shelves and furniture. One of them puts imam [Khomeini's] picture next to his picture again, camera shows the room that Basij members are completely destroying them.

At the connotative level it connotes to widespread and systematic repression and elimination of critical and independent Shia Mojtahedian and marajeseocratic (marja 'taqlīili or marja ' dīnī) in Islamic Republic of Iran's theocratic state. It connotes to widespread and systematic repression and control of critics of Ayatollah Ali Hosseini Khamenei-the second and current Supreme Leader of Iran. In other words, the independent and critical of Shiite Mojtahedian is a serious threat against Ayatollah Khamenei absolute power. It demyths the concept of valieh-faghie in the Islamic Republic of Iran's official and authorities view. Accordingly, opposition and critique of the supreme leader rule is equal to opposition to Gods, Prophet Muhammad and twelve Imam of Shia which charge could be prison, dismiss and repression. The shi'a maraje must be supporter and follower of the Islamic Republic of Iran's state and supreme leader, otherwise, they will be dismiss and eliminate from Iran's society and culture. Therefore, based on this view, they strive to dismiss, eliminate, attenuate and oppress the Iranian independent Shia Maraj-e-taqlid authorities from the society and culture and politics.

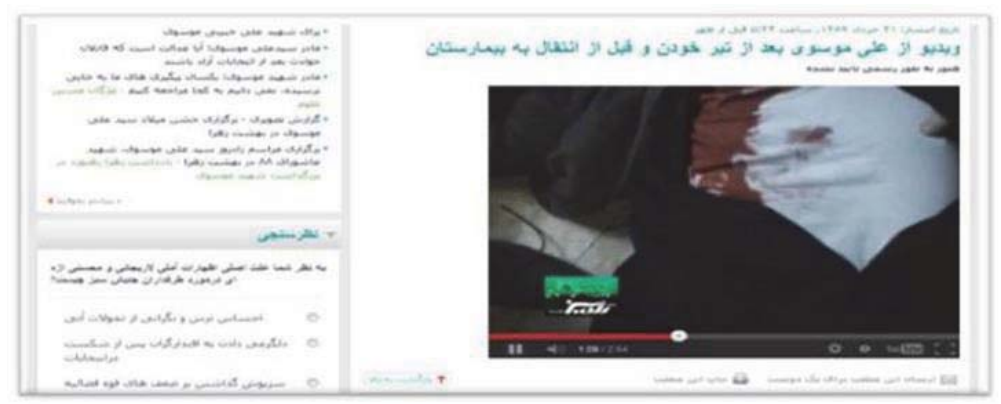

Figure 3: Still image from video clip from Sayed Ali Habibi Mousavi, http://www.rahesabz.net; 10 October 2014; @ Green Path Movement 2010 
This is a video clip from Sayed Ali Habibi Mousavi, the nephew of Mir Hossein Mousavi after he was shot and before his transfer to hospital. At the connotative level it connotes to terror of opponents, political critical and dissent family and relative by the Islamic Republic of Iran's theocratic state security forces for repression of opponents and critics. In this case, Islamic Republic of Iran's intelligence services secretly terrorized Mir Hossein Mousavi's nephew, because of repression Iranian Green Movement leaders.

At the mythical level it demyths the Shiite Islamic code about the Islamic terrorism or murder of opponents of Velayat-e Motlagh-e Faghih, jurist governance. Based on this Islamic sharia code, all people who are against Velayate-eFaghih, leader of Islamic regime must be executed and the blood can be spilled. Based on this Islamic code, the Islamic Republic of Iran's officials and authorities believe that must not have pity or compassion to Velayate-e-Faghih dissents. Accordingly, they terrorize, kill, massacre, and murder the Islamic Republic of Iran critical intellectuals and opponents to silence them.

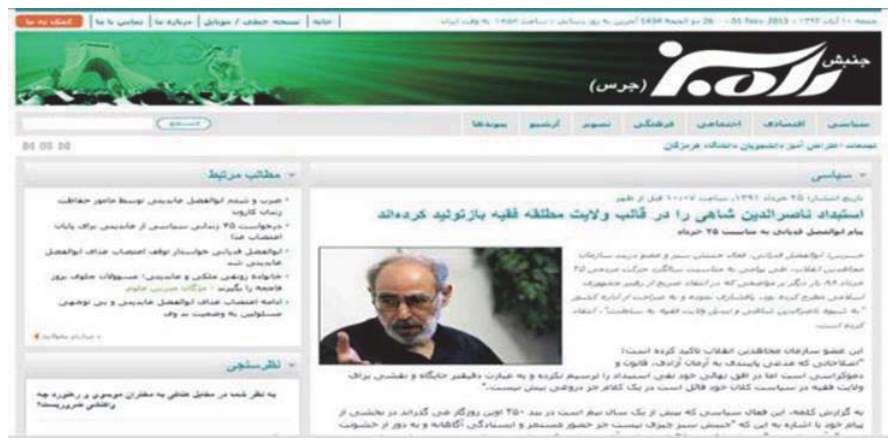

Figure 4: Abolfazl Ghadyani's published a letter about the reproduction and establishment of the sultanate in the name of Velayat-e-Motlagh-e-Faghih in the Islamic Republic of Iran's theocratic state http://www.rahesabz.net (c) Green Path Movement 2010

At the denotative level this is Abolfazl Ghadyani's public published letter from the Evine prison about the reproduction and establishment of the sultanate of 'Velayat-e Motlagh-e Faqih in the Islamic Republic of Iran's theocratic state. Abolfazl Ghadyani, a member of Mojahedin Khalgh Organization (MKO), an imprisoned political activists and critic of the Islamic Republic of Iran's supreme leader despotism argues that the Nasser al-Din Shah's sultanate of the Velayat-e Motlagh-e Faghih has been reproduced and established. In this letter, he argue that after thirty four years from Islamic revolution the ominous shadow of the religious despotism have taken over onto the innocent people of the nation, and the revolution did not achieved its purpose and failed. Abolfazl Ghadyani in his letter wrote that "our revolution is unsuccessful and we defeated because of what we upraised against it, it was absolute sultanate and personal ruling that now that relationships again has reproduced and reestablished within the template of' the Velayat-e Motlagh-e Faghih. Before the Islamic revolution, it has been tolled that Shah [Mohammad Reza Shah Pahlavi: the king of Iran] is above of laws, and today they introduce Velayate-e-Faghih above and dominate on constitution. He also shamelessly not only violate the 1979 revolution ideals but also constitutional achievements, and he took the country to Nasser al-Din Shah's era, and with issuance of what he calls rule decree, hokm-e-hokomati, personally issued law and in his speech has issued be blind and deaf.

At the connotative level it connotes to reproduction and reestablishment of absolute despotism sultanate of the Velayat-e Motlagh-e Faghih, political Islam and religious despotism. Also it connotes to similarity of the political Islam to the former monarchy system of Iran and replacement of absolute despotism sultanate of the Pahlavi monarchy system with absolute despotism sultanate of the Velayat-e Motlagh-e Faghih, political Islam and religious despotism and nothing has been changed for local people.

At the demythical level it demyth about the Islamic sultanaism, dictatorship and despotism of the concept of the Velayat-e Motlagh-e Faghih, absolute rule of the supreme jurisprudent in the political Islam. It demyth the Velayat-e Motlagh-e Faghih and political Islamic leadership as monarchism and replacement of the political Islam with monarchism and sultanate. Based on opponents of the Velayat-e Motlagh-e Faghih interpretation, valeih-e-faghih, the supreme leader authority directly drive from divine light and god, and he is representation of the god and hidden imam, imam Mahdi Shia twelve imam on earth. 


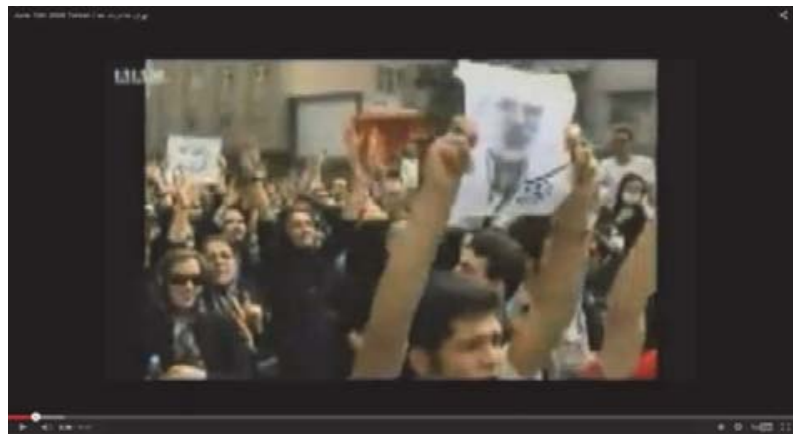

Figure 5: The screen shot of video clip from the Iranian Green Movement demonstration on 15 Jun 2009; http://www.rahesabz.net/story/17602/, 10 October 2014; @ Green Path Movement 2010

At the denotative level this is a video clip from the Iranian Green Movement demonstration on 15 Jun 2009. Although this video is published in 15 June 2010, it will be semitically analysed since it represents the Iranian Green Movement collective identity. The video clip starts with a scene of the Iranian Green Movement supporters who cheering, clapping and loudlly calling Mir Hossein Mousavi's name. In next scene, the video clip zoom in on the plakard which says "Where is my vote!". The Green Movement's supporters chanting motto of Hayhat Minna Zillah. Then the camera shows the supporters who carry Mir Hossein Mousavi's black and white picture and motto "Natarsid natarsid ma hame baham hastim" (Don't be afraid, don't be afraid we are all together and Allah-O-Akbar). The video clip also shows Mehdi Karroubi and people who support for him and finally shows Mousavi's speech on 15 June 2015.

At the connotative level it connotes to huge, massive and widespread protest against the official results of the Islamic Republic of Iran's $10^{\text {th }}$ presidential election. The video clip shows people of different social strata that standing for plurality and diversity of the Iranian Green Movement activist. It demyths contradiction of the political Islam and the Velayat-e-Motlagh-e-Faghih with people vote, democracy and demand their right to sovereignty. Based on the Islamic Republic of Iran's official and authoritative view, the legitimacy of political Islam is a divine right, and based on their interpretation from the Velayat-e Motlagh-e Faghih, and he is representative of both the big god, and also Imam Zaman-Shia Muslims twelfth imam. Therefore, based on their interpretation, people have no right to elect the president, because this is divine right and Imam Zaman's right that is given to the Velayat-e Motlagh-e Faghih and Islamic Republic of Iran's authorities. Then, they can change the people's vote in favour of Imam Zaman's right. The following example shows how the Internet website has logistic function for the Iranian oppositional groups to call people for demonstration on Quds day.

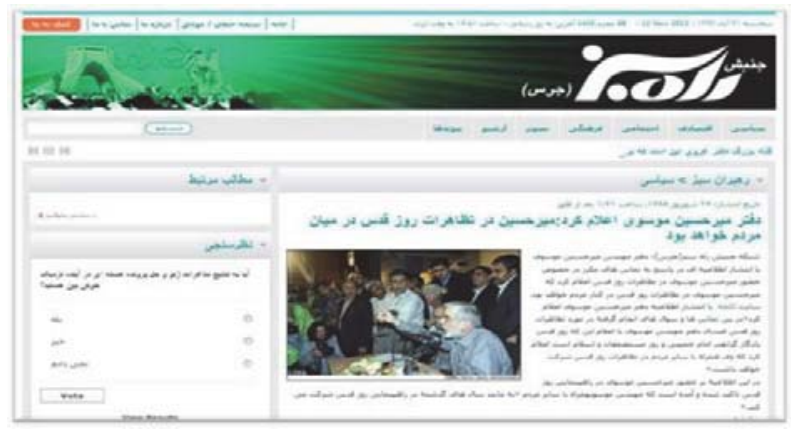

Figure 6: The first screenshot of the Green Path Movement website on Mir Hossein Mousavi participation in Quds day demonstration; http://www.rahesabz.net; 1 March 2014; @ Green Path Movement 2010

At the denotative level this is of the Green Path Movement news about Mir Hossein Mousavi attendance in demonstration on Quds day in 2009. At the connotative level Quds day is Imam Khomeini's valuable remembrance and heritages. The Quds day is the day of the libertarian world against occupation and the day of celebration of resistance and defense of 
the oppressed. Indeed who does not know that the Palestine oppressed nation and the Quds are symbol of oppression and the Zionist occupier regime is symbol of repression and rape in contemporary world. Also, at the connotative level we associate it to Iranian reformist's opposition with governmental violation, tyranny, occupation, rape, forging and oppression and governmental terrorism and Iranian reformist resistance against the Islamic Republic of Iran's government terrorism, occupation and violence.

At the demyhtical level it demyth the Quds day in the Islamic Republic of the Iran's political culture. Based on this cultural code, Israel has occupied Palestinians lands, and all Muslim demonstrate against this occupation. The Iranian Green Movement's protesters also believe that the Islamic government occupied Iran and they protest against their occupation. Also, it demyth the Islamic Republic of Iran's theocratic state occupation of the Iranian land. The example below shows how the Internet has been used by Iranian oppositional groups for reconstruction and representation of their collective identities against the dominant or mainstream identity.

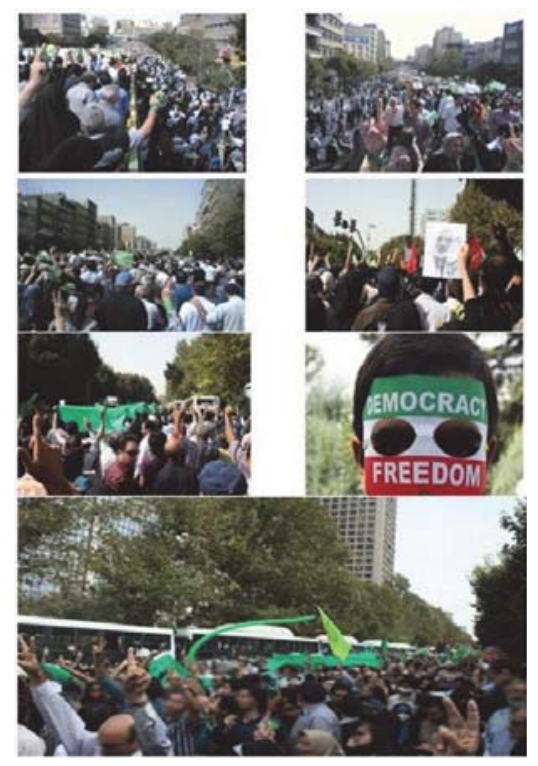

Figure 7: Collective photographs the Iranian Green Movement supporters demonstration on the Quds day in 2009; http://www.rahesabz.net: 2 February 2015; @ G Green Path Movement 2010

At the denotative level these are photographs of the Iranian Green Movement supporters who demonstrate against the Islamic Republic of ambiguous policy on the Quds day in 2009. The first photography is a long shot from the Iranian Green Movement supporters who demonstrate against the Islamic Republic At the second and third photograph, participants raised up green colour placards on which is written "Russia shame of you", "No Gazzah No Lebanon", "Just Iran plateau" and so on. At the fourth photograph the protestors raised up Mir Hossein Mousavi picture and at the next photograph, the Green Movement participant carries green colour clothes. Finally, the last photography shows protesters who carry green colour clothes, balloons and raised their hand in $v$ shape.

At the connotation level it connotes to the Iranian Green Movement disagreement with the Islamic Republic of Iran's state foreign policy against Palestine, Lebanon and United States. Also it connotes to series contradiction and conflict between Islamic Republic of Iran's opponents and proponents in Iran's society. It also connotes to the Iranian green movements activists struggle and resistance against the Islamic Republic of Iran tyranny and oppression. It stands for collectivity, secularization, democratization, nationalism and peacefulness of the Iranian Green Movement's identity.

At the demyhtical level it demyth the Quds day in the Islamic Republic of the Iran's political culture. Based on this cultural code, Israel has occupied Palestinians lands, and then all Muslim demonstrate against this occupation. The Iranian Green Movement's protesters also believe that Islamic government occupied Iran and they protest against their occupation. The example below shows how the Internet becomes a site for Iranian oppositional groups, Internet activists, and subcultures to develop their solidarity and alliance to overcome the postmodern identity politics. 


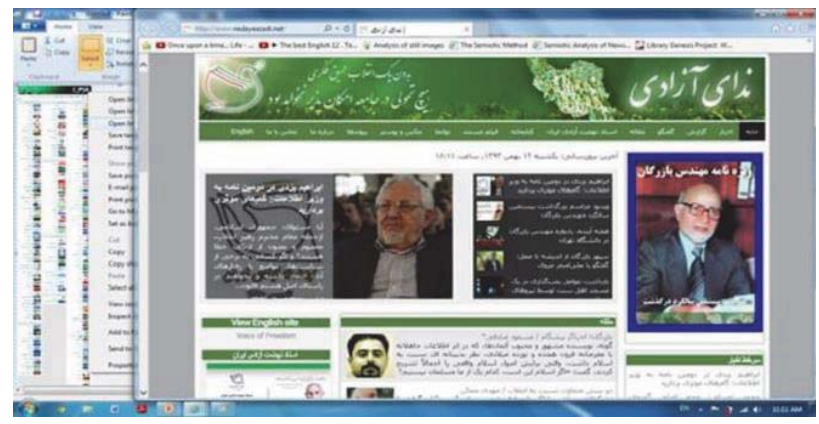

Figure 8: The first screenshot of the link page for the Green Path movement website; http://www.rahesabz.net and front page of the first screenshot of the voice of freedom Website Homepage; http://www.nedayeazadi.net (c) Green Path Movement 2010

At the denotative level this is the first Screenshot of the link page the Green Path Movement website, http://www.rahesabz.net_and front page of the first screenshot of the Neday Azadi website, http://www.nedayeazadi.net. The link page of the Green Path Movement website include seven categories as follow; link to news agencies and news websites, foreign news websites, personal websites and weblogs, newspapers (published in Iran), cultural and application websites, radio and television and organizations and institutions.

At the connotative level it connotes to online alliance and solidarity between the Iranian Green Movement liberal democrat activists and the Iranian reformist political writers and analysts. Also it connotes to alliance and solidarity between like-minded groups and like-minded network. In another word, it connotes to the online convergence between like-minded groups and divergence between reformist and oppositional groups. At the mythical level it demyth the expansion of doctrine of reformism, liberalism and democratization between the both of the Iranian Green Movement activists and the groups. The following example shows how the Internet becomes site for the Iranian oppositional groups for direct expression of their political and cultural protest. The following example shows the tactical function of the Internet for direct expression of political struggles.

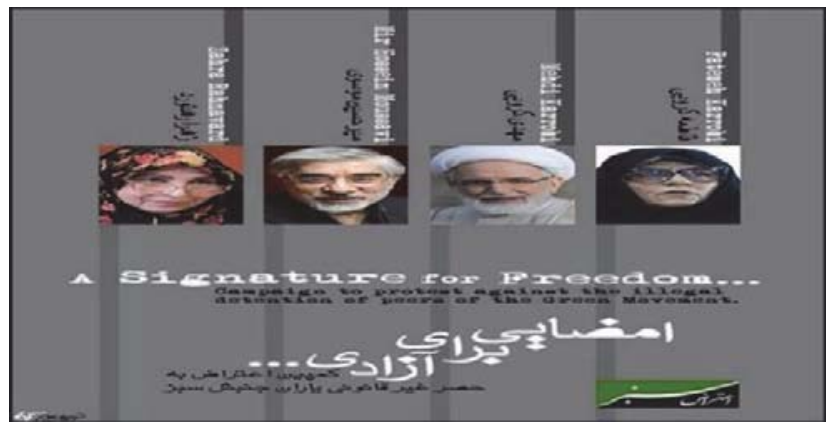

Figure 9: Signing online petition for the Release of Mir Hossein Mousavi, Mehdi Karroubi \& Their Spouses; http://www.kaleme.com: without permission, 2 February 2015; @ Green Path Movement 2010

At the denotative level this is the public's demand to end the illegal detention of the champions of the Green Movement-Zahra Rahnavard, Mir Hossein Mousavi, Mehdi Karroubi, and Fatemeh Karroubi. The background of the poster is in gray colour that stands for ambiguity. From the left side, the first photograph is that of Zahra Rahnavard, former chancellor of Alzahra Uuniversity; Mir Hossein Mousavi Khameneh's wife who wears a colourful scarf, chador and glasses. The second picture is that of Mir Hossein Mousavi Khameneh, Prime Minister of Iran (1981-1989) and Minister of Foreign Affairs of Iran (1981-1981) who is wearing a simple hair style, white and gray coloured hair, glasses, beard and moustache and suit. The third picture is that of Mehdi Karroubi, the chairman of parliament from 1989 to 2004, also the chairman of the National Trust Party who is wearing a white-coloured turban, glasses, white beard and mustache. The fourth photograph 
is that of Fatemeh Karroubi, the wife of Mehdi Karroubi, who is wearing black chador, and glasses. Below the photographs, written in English language in bold font and white colour is the Signature for Freedom, a campaign to protest against the illegal detention of peers of the Green Movement. Below the sentence in the Persian language is the signature for freedom, a protest campaign against the illegal home arrest of peers of the Green Movement. On the right bottom corner, there is a rectangle covered black and green on which is written the Green Protest in the Persian language.

At the connotation level it connotes to the home arrest of the politically critical leaders and intellectuals by the Islamic Republic of Iran's theocratic system. Also, it connotes the lack of freedom of expression in the Islamic Republic of Iran's theocratic state such that anyone who criticizes the political system is arrested or put under home arrest. At the mythical level it demyths the orthodox Shiite Islamic clergies view about the opponent of Velayate-e-Faghih, jurist governance. Based on this Islamic sharia code, all people who are against Velayate-e-Faghih, leader of the Islamic regime must be silenced, imprisoned, executed and whose blood can be spilled. According to their view, the Islamic Republic of Iran's officials and authorities believe that there must be no pity or compassion for Velayate-e-Faghih dissenters, so accordingly, they are placed under home arrest, arrested, imprisoned, assassinated executed and terrorizes.

\section{Discussion}

The Iranian Green Movement's activists launched their own website to advance their cultural and political struggles against the repressive and despotic policies of the Islamic Republic of Iran's theocratic state. Figures 2, 3, 5 and 7 demonstrate that the Iranian Green Movement activists have used the Internet for production and dissemination of alternative forms of information, culture and meaning for the representation and reconstruction of a collective identity beyond the limits of the mainstream, state and local media. As Figure 6 shows, the Internet has been used by the Iranian oppositional movement to organize and mobilize public demonstrations against the Islamic Republic of Iran's oppressive policies. The data of this study show that the Internet as a networked system can be used by the oppositional movement for development of their alliance and solidarity with other organizations, groups and individuals. For example, as Figure 8 shows, there is a link between the Iranian Green Path Movement's website and the Neday Azady website which approve the article argument about network feature of the World Wide Web.

Although the study shows that there is a link between this group and other groups, it is a connection limited to likeminded groups and these groups dismissed Iranian leftists and oppositional groups who also struggle against the repressive policies of the Islamic Republic of Iran's theocratic state. Accordingly, it could be argued that the Internet as contested terrain or as an alternative media, on the one hand, can contribute to solidarity and integration of communities and on the other hand, the Internet can enhance fragmentation and cyberbalkanization of the communities to like-minded groups. Figure 9 shows that the Internet as an alternative media has been used by the oppositional movements as both a weapon and a target of direct expression of their political protest and struggles. Of course, it should be mentioned that the website operators do not use the full potential of the Internet technology as weapon and target of direct expression of their political protests. They have never used culture jamming, hachtivism, and email bombing/virtual sit-ins against the Islamic Republic of Iran's oppressive policies. However, the findings of the study show effectiveness of the website of the Iranian Green Movement's in the Qouds day demonstration. Beside, the finding of the study shows that the website has never criticized the Islam religion as a main factor of hegemonic system ideology. Still, we don't know anything about political economy of the website, audience of the website and its effect on audience receptions

The findings of the study support some of the arguments by Kahn and Kellner $(2003,2005,2007)$ on the oppositional deployment of the Internet to promote their political interests and agendas. The finding shows that the Iranian Green Movement's activists have been using the Internet and the websites as instruments of their political struggle to mediate and circulate the message about their struggles against election policies of the Islamic Republic of Iran. Instead of widespread and systematic control and repression of the Internet activists, the Iranian Green Movement's activists reconstructed, reshaped, reformed and reused the technologies for their "self-valorization", "self-empowerment", self-representation and mediation and circulation of their struggles against the oppressive policies of the Islamic Republic of Iran. It should mentioned that, however, our finding shows that the Internet has been used by the Iranian Green Movement activists for advance of their political struggles, But, it does not mean that they neglect the strict role of the Iranian authoritarian state in widespread and systematic censorship, shutting down and blocking the Internet and website contents, slowing the internet speed, detaining Green Movements blogger and writers, and tapping their cell phones.

In contrast to the proponents of new information and communication technologies (Grossman, 2009; Howard et al., 2011; Michaelsen, 2011) who said that the Internet or new media substantially strengthens oppositional movements in 
Iran, the findings of the study show that the Internet has been comprehensively utilized by the Islamic Republic of Iran's totalitarian system for control and suppression of the Iranian Green Movement. Furthermore, instead of the widespread and systematic control and suppression of the Green Movement's activists, the Internet has also contributed to fragmentation and "cyberbalkanization" communities and groups to "like-minded" groups which may weaken the Iranian Green Movement.

In contrast to the opponents of information and communication technologies (Morozov, 2011; Schiller, 2000; Webster, 1999) a pessimistic outlook which claims the Internet reinforced, strengthened, and reestablished the ruling forces of totalitarian state, the findings shows that instead of widespread and systematic control and censorship of the Internet, the Iranian Green Movement's activists reconstructed, reshaped, reformed and reused the technologies for their "self-valorization", "self-empowerment", "self-representation" and mediated and circulated the message of their struggles against the oppressive policies of the Islamic Republic of Iran's theocratic state.

Different from the postmodern scholar Baudrillard's (Baudrillard, 1983a, 1983b; Baudrillard \& Levin, 1981) view, mass media images are meaningless, flatness, depthlessness and superficial, Kellner (2003) argues that media images are meaningful and ideological, and this present paper argues that the alternative media texts, especially unedited, unrevised, and unaffected photographs and video clips are meaningful and ideological. It is similar to Barthes's (1977) perspective that photography represents and reveals the culture and ideology of dominant systems and totalitarian states, the article argues that the alternative media of photography and video clips depict the totalitarian state's hegemonic culture, identity, and ideology.

Similar to Kahn and Kellner's (2004) perspective that argues the World Wide Web's networked feature facilitates link between several diverse sub-cultures and groups which promote politics of alliance and solidarity between diverse groups and sub-cultures, the study data show that the Internet as networked system can be used by the opposition movement for development of their alliance and solidarity with other organizations, groups and individuals. For example, as Figure 8 features there is a link between the Neday Azady website with the Iranian Green path Movement's website which demonstrates that the Internet as networked system can be used by the opposition movement for development of their alliance and solidarity with other organizations, groups and individuals. Difference to Kahn and Kellner's (2004) perspective the finding of the study show that there is no external link between the website of Neday Azady and Iranian leftists and opposition groups who also struggle against the repressive policies of the Islamic Republic of Iran's theocratic state which can be interpreted as weak connection and connection limited to like-minded groups which may weakened social movement. Therefore, it can be argued that the new information and communication technologies as a contested terrain or as an alternative media, on the one hand can contribute to solidarity and integration of communities and on the other hand, the new information and communication technologies can enhance fragmentation and cyberbalkanization of the communities to only like-minded groups and networks.

Similar to Vegh's (2003) argument, the findings of the study illustrate that the Net and the websites, on the one hand, provide the Iranian Green Movement with a cheap and fast means of communication which facilitate people for online and offline organization and mobilization of public demonstrations and protests. The difference with Vegh's (2003) argument of the findings of this study is that the Internet and the World Wide Web, on the other hand, facilitate the disorganization of public demonstration by informing and creating awareness of the Islamic Republic of Iran's security forces from details of demonstration time and venue. Consequently, it can be argued that the Internet as a tool has dual functions for organization and disorganization of public demonstrations, so that both the dominant forces and struggles can use the technologies for promotion of their own political and cultural aims and projects.

Similar to Laer et al. (2010) argument that represented a twofold typology of a new digitalized collective action repertoire for social movements, the finding of the study shows that the Internet, on the one hand, can facilitate and support traditional offline collective action in terms of organization, mobilization, and transnationalization such as street demonstrations, rallies, and strikes and the Internet, on the other hand, creates virtual modes of collective action in terms of alternative website and weblog creation, signing online petitions, cultural jamming, hacking, and email bombings

\section{Conclusion}

To conclude, the example in this article shows how that the Internet as a "contested terrain" or as "alternative multimedia" has been used by oppositional movement for the promotion of their political interests and agendas. In this conjuncture, the finding of the study support Kahn \& Kellner (2004) perspective that argue that the Internet as a "contested terrain" or as an "alternative media" can be used by both ruling and resistance forces for promotion of their political projects and ends. From their (2007) viewpoint much significant political struggles are mediated by Techno-politics in the age of new technologies. They further argue that deploying computer-mediated technology for "techno-politics" opens a new terrains 
of political struggles for oppressed and excluded groups those who dismissed from mainstream media and thus increases potential for resistance and struggles by oppositional groups.

This paper focused on how information and communication technologies--the Internet and the World Wide Web can be used by the Iranian Green Movement's activists to promote their political and cultural struggles. This article studied contemporary oppositional movements, particularly Internet use by the Iranian oppositional movements online and offline for purposes of alternative forms of cultures and information production, representation and reconstruction of collective identity, the organization and mobilization of public demonstration, the networking and development of alliance and solidarity between oppositional movement's activists, and the direct expression of political protests to facilitate the movement's struggles against the Islamic Republic of Iran's oppressive policies.

Therefore, it could be argued that the Internet technologies as a "contested terrain" or as an alternative multimedia have dual functions for the oppositional groups for promotion of their political struggles. The Internet, on the one hand, helps to diffuse the ideological message of the Iranian oppositional movements, the Internet, on the other hand, highlighted the ideological contradiction between the Iranian oppositional movements. The net and the websites, on the one hand, provides the Iranian Green Movements with a cheap and fast means of communication which simplifies organization and mobilization of public demonstration and protests, and, the internet and the World Wide Web, on the other hand, make facilitated the disorganization of public demonstration by the Islamic Republic of Iran's security forces. The Internet on the one hand can contribute to alliance and solidarity between communities and groups and on the other hand, can enhance fragmentation and cyberbalkanization of the communities and groups to the like-minded groups.

In summary, the paper concludes that the Internet as a "contested terrain" or as an alternative multimedia has been used by the Iranian Green Movement's activists for the promotion of their political and cultural struggles against the Islamic Republic of Iran's state' oppressive policies. By oppositional deployment of the Internet technologies, the Iranian Green Movement's activists mediate their political struggles against repressive and oppressive policies of the Islamic Republic of Iran's theocratic state. Deploying the Internet technology for techno-politics, however, opens new terrains of political struggle for voices and groups excluded from the mainstream media and thus increase potential for resistance and intervention by oppositional groups. Therefore, the Iranian internet activists who are interested in political and cultural struggle for democratization and progressive transformation of societies need to acquire new forms of technological literacy to intervene in the new public spheres of the media and information society.

\section{Refrences}

Aday, S., Farrell, H., Lynch, M., Sides, J., Kelly, J., \& Zuckerman, E. (2010). Blogs and bullets: New media in contentious politics. New York: Institute of Peace

Atton, C. (2001). Alternative media. London, Thousand Oaks and New Delhi: Sage.

Ayres, J. M. (1999). From the streets to the Internet: The cyber-diffusion of contention. The Annals of the American Academy of Political and Social Science, 566(1), 132-143.

Baringhorst, S. (2008). Political protest on the net. German Policy Studies, 4(4), 63-93.

Barthes, R. (1968). Elements of semiology. New York: Hill and Wang.

Barthes, R. (1972). Mythologies (A. Lavers, Trans.). New York: The Noonday Press.

Barthes, R. (1977). Image-Music-Text. (S. Heath, Trans.). London: Fontana Press.

Baudrillard, J. (1983b). In the shadow ofthe silent majorities... or the End of the social and other essays. Trans. Paul Foss, Paul Patton and John Johnston. New York: Semiotext (e).

Baudrillard, J., \& Levin, C. (1981). For a critique of the political economy of the sign. New York: Telos Press Publishing.

Bennett, W. L., \& Segerberg, A. (2011). Digital media and the personalization of collective action: Social technology and the organization of protests against the global economic crisis. Information, Communication \& Society, 14(6), 770-799.

Best, S., \& Kellner, D. (1998). Postmodern politics and the battle for the future. New Political Science, 20(3), 283-299.

Castells, M. (2001). The Internet galaxy: Reflections on the Internet, business, and society. New York: Oxford University Press, Inc.

Chandler, D. (2000). Semiotics for beginners: Daniel Chandler.

Della Porta, D., \& Mosca, L. (2005). Global-net for global movements? A network of networks for a movement of movements. Journal of Public Policy, 25(1), 165-190.

DiMaggio, P., Hargittai, E., Neuman, W. R., \& Robinson, J. P. (2001). Social implications of the Internet. Annual Review of Sociology, 27, 307-336.

Downey, J., \& Fenton, N. (2003). New media, counter publicity and the public sphere. New Media \& Society, 5(2), 185-202.

Downing, J. (2008). Social movement theories and alternative media: An evaluation and critique. Communication, Culture \& Critique, 1(1), 40-50.

Grossman, L. (2009). Iran protests: Twitter, the medium of the movement. Time Magazine, 17.

Hick, S., \& McNutt, J. (2002). Communities and advocacy on the internet: A conceptual framework. Advocacy, activism and the internet: Community organization and social policy, 3-18. 
Kahn, R., \& Kellner, D. (2003). Internet subcultures and oppositional politics. In R. W. D Muggleton (Ed.), The post-subcultures reader. the University of Michigan: Berg.

Kahn, R., \& Kellner, D. (2004). New media and internet activism: From the 'Battle of Seattle' to blogging. New Media \& Society, 6(1), 8795.

Kahn, R., \& Kellner, D. (2005). Oppositional politics and the Internet: A critical/reconstructive approach. Cultural Politics, 1(1), 75-100.

Kahn, R., \& Kellner, D. (2007). Globalization, technopolitics and radical democracy. In L. Dahlberg \& E. Siapera (Eds.), The Internet and Radical Democracy: Interrogating Theory and Practice. (pp. 17-36). London: Palgrave.

Kamalipour, Y. R. (2010). Media, power, and politics in the digital age: the 2009 presidential election uprising in Iran. Lanham, Boulder, New York, Toronto, Plymouth and UK: Rowman \& Littlefield Publishers.

Kellner, D. (1999). New Technologies: Technocities and the Prospects for Democratization. In J. Downey \& J. McGuigan (Eds.), Technocities: The culture and political economy of the digital revolution. London, Thousand Oaks and New Delhi: Sage.

Kellner, D. (2001). Globalisation, Technopolitics and Revolution. In J. Foran (Ed.), Theoria: A journal of social and political theory. London and New York: Zed Books.

Kellner, D. (2003). Media culture: Cultural studies, identity and politics between the modern and the post-modern. London and New York: Routledge.

Kress, G. R., \& Van Leeuwen, T. (2006). Reading images: The grammar of visual design. London and New York: the Taylor \& Francis eLibrary.

McAdam, D., Tarrow, S., \& Tilly, C. (2003). Dynamics of contention. Social Movement Studies, 2(1), 99-102.

Michaelsen, M. (2011). Linking up for change: The internet and social movements in iran. In N.-C. Schneider \& B. Gräf (Eds.), Social dynamics 2.0: Researching change in times of media convergence: case studies from the Middle East and Asia. Germany: Frank \& Timme $\mathrm{GmbH}$.

Morozov, E. (2011). The Net Delusion: How not to liberate the world. London: Penguin UK.

Movement, t. G. P. (2010). 26 June 2013, from; http://www.rahesabz.net

Pickerill, J. (2006). Radical politics on the net. Parliamentary Affairs, 59(2), 266-282.

Rahimi, B. (2011). The agonistic social media: cyberspace in the formation of dissent and consolidation of state power in postelection Iran. The Communication Review, 14(3), 158-178.

Schiller, D. (2000). Digital capitalism: Networking the global market system. Cambridge, Massachusetts, London, England: MIT press.

Sreberny, A., \& Khiabany, G. (2010). Blogistan: The internet and politics in Iran. London and New York: I.B. Tauris.

Stein, L. (2009). Social movement web use in theory and practice: A content analysis of US movement websites. New Media \& Society, $11(5), 749-771$.

Tilly, C., \& Tarrow, S. (2006). Contentious politics. New York: Oxford University Press.

Van Aelst, P., \& Walgrave, S. (2002). New media, new movements? The role of the internet in shaping the 'anti-globalization'movement. Information, Communication \& Society, 5(4), 465-493.

Van De Donk, W., Loader, B. D., Nixon, P. G., \& Rucht, D. (2004). Cyberprotest: New media, citizens and social movements. London and New York: Routledge.

Van Laer, J., \& Van Aelst, P. (2010). Internet and social movement action repertoires: Opportunities and limitations. Information, Communication \& Society, 13(8), 1146-1171.

Vegh, S. (2003). Classifying forms of online activism. In M. D. A. Martha McCaughey (Ed.), Cyberactivism: Online activism in theory and practice (pp. 71-95). London and New York: Routledge.

Warf, B., \& Grimes, J. (1997). Counterhegemonic discourses and the Internet. Geographical Review, 87(2), 259-274.

Webster, F. (1999). Information and communications technologies: Luddism revisited. In J. D. a. J. McGuigan (Ed.), Technocities: The culture and political economy of the digital. London: Sage.

Wojcieszak, M., \& Smith, B. (2014). Will politics be tweeted? New media use by Iranian youth in 2011. New Media \& Society, 16(1), 91109. 